\title{
Seasonal variation in gas exchange and chlorophyll index of Palicourea racemosa in an open ombrophilous forest
}

\author{
Variación estacional en el intercambio de gases y el índice de clorofila \\ de Palicourea racemosa en un bosque ombrófilo abierto
}

\begin{abstract}
Ester dos Santos Coêlho a , João Everthon da Silva Ribeiro ${ }^{\text {b*, }}$ Francisco Romário Andrade Figueiredo a Arliston Pereira Leite ${ }^{c}$, Marlenildo Ferreira Melo a, Manoel Bandeira de Albuquerque ${ }^{c}$

${ }^{a}$ Federal Rural University of Semi-arid (UFERSA), Department of Plant Sciences, Mossoró, Rio Grande do Norte, Brazil.

*Corresponding author: ${ }^{b}$ State University of Maranhão (UEMA), Department of Technology in Agribusiness Management, Strees Hernani Pereira n458, Itapecuru-Mirim, Maranhão, Brazil, tel.: +558398171-6327, j.everthon@hotmail.com

${ }^{\mathrm{c}}$ Federal University of Paraiba (UFPB), Department of Phytotechnics and Environmental Sciences Areia, Paraiba, Brazil.
\end{abstract}

\begin{abstract}
SUMMARY
Seasonal variation affects understory and canopy tree plants in different ways. Palicourea racemosa is an understory shrub from the Rubiaceae family and is subject to seasonal oscillations of the environment, which can affect plant ecophysiological responses. This species is widely distributed in humid forests from southern Mexico to southeastern Brazil and has broad economic and ecological importance for the regions of occurrence, being used for food, ornamental and traditional medicine purposes. It is of fundamental importance to know ecophysiological responses of this species throughout dry and rainy periods, to understand the dynamics of understory plants in tropical forests. This research aimed at evaluating the effects of seasonality on ecophysiological aspects of $P$. racemosa at the Mata do Pau-Ferro State Park, municipality of Areia, Paraíba, Brazil. Over ten months, upper canopy structure indices were measured in ten individuals, climatic data were collected and their effects on gas exchange and chlorophyll indices in plants were evaluated. Results showed that the environmental variables correlated with the ecophysiological ones, with a strong association of soil moisture, rainfall and leaf area index of the upper canopy on ecophysiological aspects in $P$. racemosa plants, indicating that water availability and irradiance affect gas exchanges and photosynthetic pigment content. Except for intrinsic water use efficiency and instantaneous carboxylation efficiency, all ecophysiological variables showed significant differences over the months, showing the influence of seasonality on the ecophysiological responses of P. racemosa.
\end{abstract}

Key words: photosynthesis rate, physiological responses, Rubiaceae, understory vegetation, water availability.

\section{RESUMEN}

La variación estacional afecta a las plantas de árboles del sotobosque y del dosel de diferentes maneras. Palicourea racemosa es un arbusto de sotobosque de la familia Rubiaceae y está sujeto a oscilaciones estacionales del medio ambiente, que pueden afectar las respuestas ecofisiológicas de las plantas. Esta especie se encuentra ampliamente distribuida en bosques húmedos desde el sur de México hasta el sureste de Brasil y tiene una gran importancia económica y ecológica para las regiones de ocurrencia, siendo utilizada con fines alimentarios, ornamentales y de medicina tradicional. Es de fundamental importancia conocer las respuestas ecofisiológicas de esta especie a lo largo de los períodos secos y lluviosos, a fin de buscar comprender la dinámica de las plantas del sotobosque en los bosques tropicales. La investigación tuvo como objetivo evaluar los efectos de la estacionalidad en aspectos ecofisiológicos de P. racemosa en el Parque Estatal Mata do Pau-Ferro, municipio de Areia, Paraíba, Brasil. Durante diez meses, se midieron índices de estructura del dosel superiores a diez individuos, se recopilaron datos climáticos y se evaluaron sus efectos sobre el intercambio de gases y los índices de clorofila en las plantas. Las variables ambientales se correlacionaron con las ecofisiológicas, con una fuerte asociación de la humedad del suelo, las precipitaciones y el índice de área foliar del dossel superior en los aspectos ecofisiológicos de $P$. racemosa, resultados que indican que la disponibilidad de agua y la irradiancia afectan los intercambios de gases y el contenido de pigmentos fotosintéticos en las plantas. Excepto, por la eficiencia intrínseca del uso del agua y la eficiencia de la carboxilación instantánea, todas las variables ecofisiológicas tuvieron diferencias significativas a lo largo de los meses, debido a la influencia de la estacionalidad en las respuestas ecofisiológicas de P. racemosa.

Palabras clave: tasa de fotosíntesis, respuestas fisiológicas, Rubiaceae, vegetación del sotobosque, disponibilidad de agua. 


\section{INTRODUCTION}

Tropical forests are terrestrial ecosystems that have broad productivity and abundant species diversity, being fundamental in the formation of ecological niches (Pausas and Bond 2020). Among the different physiognomies found in this ecosystem, seasonal forests stand out for presenting ecological and physiological adaptations to each climatic season (Derroire et al. 2016). During the dry season, 30 to $50 \%$ of individuals in the forest canopy are deciduous and shed leaves as an adaptation mechanism to water deficit (Vijith and Dodge-Wan 2020).

Climatic seasons directly influence growth, development, propagation and physiology of canopy forest species, as well as affect the understory vegetation, which is composed by shrubs, sub-shrubs, terrestrial herbs and young trees from the forest canopy (Denslow et al. 2019). Understory species are affected by different factors, which can be altered according to seasonal variations in environmental conditions that consequently modify the ecological and ecophysiological activities of plants (Lambers and Oliveira 2019). Among the abiotic factors that most influence understory plants are water availability, light intensity and temperature (Giuggiola et al. 2018, Elias et al. 2019).

Water availability is one of the main environmental factors regulating plant growth, development and photosynthetic capacity. In the photosynthetic process, water deficit induces stomatal closure and limits $\mathrm{CO}_{2}$ concentration in the mesophyll, which thus hinders $\mathrm{CO}_{2}$ fixation and transport of photoassimilates throughout the plant (Baraket et al. 2020).

Another important environmental factor regulating physiological processes in understory species is light. Irradiance either intensifies the photosynthetic apparatus activity or reduces it due to photoinhibition caused by excess light (Sun et al. 2020). Moreover, irradiance variation inside the understory changes the forest microclimate, as air and soil temperatures. Such variation depends on factors relating to canopy structure, such as the opening of natural clearings and leaf shedding during the dry season (Mansur 2017).

Light availability in the understory in forest ecosystems can be measured using variables related to forest canopy, such as leaf area index (LAI), visible sky fraction (VSF) and photosynthetically active radiation (PAR). Different techniques have been used to analyze the canopy structure and light transmission, such as using hemispheric photographs and LAI meters by solar radiation attenuation (Jenicek et al. 2018).

Among the understory species, Palicourea racemosa (Aubl.) G.Nicholson (Rubiaceae) is a neotropical plant, $4 \mathrm{~m}$ in height widely distributed in humid forests from southern Mexico to southeastern Brazil (Zappi et al. 2017). This species has high economic and ecological importance for the regions of occurrence, being used for food and ornamental purposes and, in phytochemical-based tra- ditional medicine, for the treatment of neurodegenerative diseases (Calixto et al. 2016).

We hypothesized that: (1) The ecophysiological aspects of the understory species, P. racemosa, are influenced by seasonal variation; (2) The plants present strategies to acclimate to the dry period, such as reducing transpiratory rate and stomatal conductance, tolerating water scarcity in the soil and high irradiance; (3) The species has phenotypic plasticity to respond to seasonal variation in light availability and soil water content, with changes in ecophysiological aspects. Thus, this research evaluated the effects of seasonal variation on ecophysiological aspects in $P$. racemosa.

\section{METHODS}

Experimental area. The study was carried out at Parque Estadual Mata do Pau-Ferro (6 $6^{\circ} 58^{\prime} 12^{\prime \prime}$ S, 35 $42^{\prime} 15^{\prime}$ ” W), an approximately 600 ha area located $5 \mathrm{~km}$ west from Areia City, state of Paraíba, Northeast Region, Brazil (figure 1). The climate of the region is classified as Aw (Peel et al. 2007), which is hot and humid tropical with autumnwinter rains, with annual rainfall ranging from 800-1,600 $\mathrm{mm}$, and average annual temperature of $22{ }^{\circ} \mathrm{C}$. Topography is from undulating to strong undulating.

Data collection. For environmental and ecophysiological data collection, ten adult individuals with average $2.10 \mathrm{~m}$ in height and $16 \mathrm{~cm}$ in diameter at breast height were randomly selected, and their geographic locations were georeferenced (figure 1). Evaluations were performed from January to September 2018. Climatic data [rainfall and temperature (average, maximum and minimum)] during this period are shown in the ombrothermic diagram (figure 2). Precipitation and temperature data were collected monthly by the Meteorological Station of Center for Agricultural Sciences, Federal University of Paraíba, Campus II (Areia Station - A310, code OMM 81877), about 3.5 linear kilometers from the study area.

To perform an edaphic characterization, four soil samples $(0-20 \mathrm{~cm}$ depth) were collected under the canopy of each $P$. racemosa plant. After, these samples were combined to form a composite sample from which a sample was taken for soil chemical and granulometric evaluation (table 1).

Gas exchange. To assess the plant gas exchange, the net assimilation rate of $\mathrm{CO}_{2}\left(\mathrm{~A}, \mu \mathrm{mol} \mathrm{m} \mathrm{m}^{-2} \mathrm{~s}^{-1}\right)$, stomatal conductance (gs, mol m $\left.\mathrm{m} \mathrm{s}^{-1}\right)$, transpiration rate $\left(\mathrm{E}, \mathrm{mmol} \mathrm{m}^{-2} \mathrm{~s}^{-1}\right)$ and intercellular $\mathrm{CO}_{2}$ concentration $\left(\mathrm{Ci}, \mu \mathrm{mol} \mathrm{mol}^{-1}\right)$ were measured using a portable Infrared Gas Analyzer (IRGA) (model LI-6400XT LI-COR, Inc., Lincoln, NE, USA). Afterwards, transpiration efficiency [instantaneous water use efficiency, WUE $\left.=\mathrm{A} / \mathrm{E},\left(\mu \mathrm{mol} \mathrm{m}^{-2} \mathrm{~s}^{-1}\right)\left(\mathrm{mmol} \mathrm{m}^{-2} \mathrm{~s}^{-1}\right)^{-1}\right]$, intrinsic water use efficiency [iWUE $=\mathrm{A} / \mathrm{gs},\left(\mu \mathrm{mol} \mathrm{m}^{-2} \mathrm{~s}^{-1}\right)$ $\left.\left(\mathrm{mol} \mathrm{m} \mathrm{m}^{-2} \mathrm{~s}^{-1}\right)^{-1}\right]$ and instantaneous carboxylation efficiency 


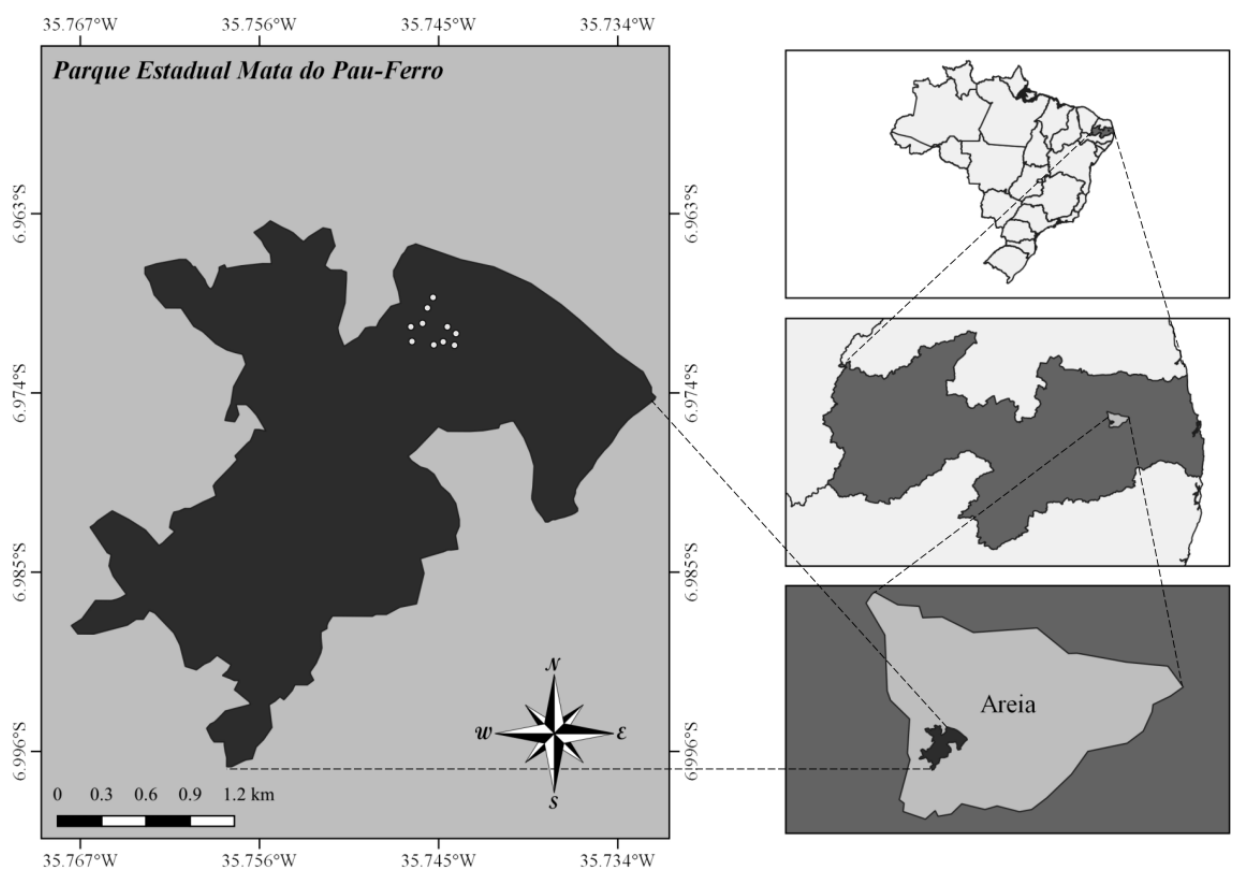

Figure 1. Geographic location of P. racemosa individuals at Parque Estadual Mata do Pau-Ferro, Areia, Paraíba, Brazil.

Ubicación geográfica de individuos de P. racemosa en el Parque Estadual Mata do Pau-Ferro, Areia, Paraíba, Brasil.

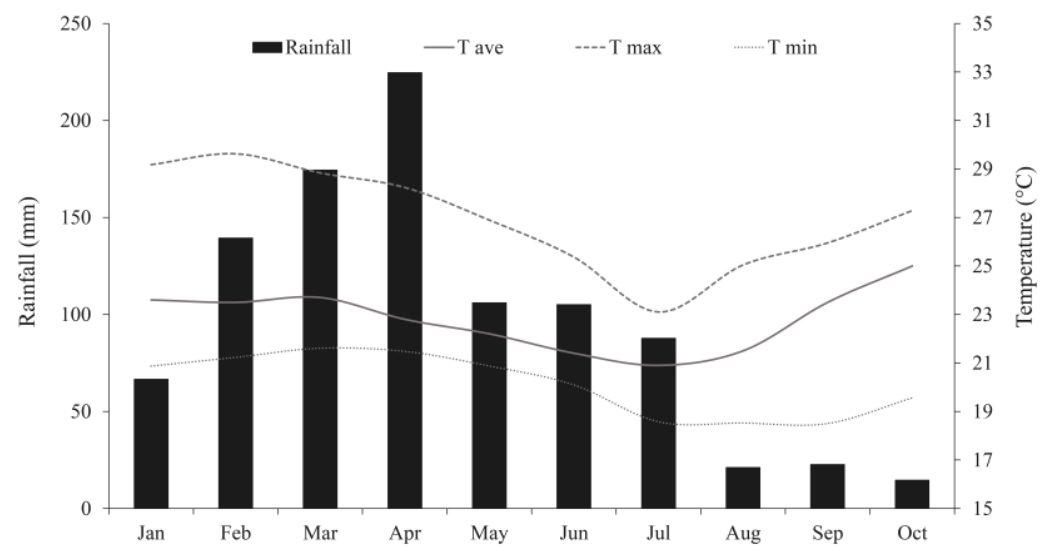

Figure 2. Rainfall, average temperature ( $\mathrm{T}$ ave), maximum temperature ( $\mathrm{T}$ max) and minimum temperature ( $\mathrm{T}$ min) recorded at the meteorological station from Center of Agrarian Sciences, Federal University of Paraiba (Campus II, Estação Areia - A310, code: OMM 81877) during the months of 2018 in which the collections were carried out (Source: Instituto Nacional de Meteorologia - INMET).

Lluvia y temperatura registradas en la estación meteorológica del Centro de Ciencias Agrarias, Universidad Federal de Paraíba (Campus II, Estação Areia - A310, código: OMM 81877) durante los meses de 2018 en los que se realizaron las recolecciones (Fuente: Instituto Nacional de Meteorología - INMET).

Table 1. Chemical and granulometric attributes in $0-20 \mathrm{~cm}$ soil at Parque Estadual Mata do Pau-Ferro, Areia, PB.

Atributos químicos y granulométricos de los $20 \mathrm{~cm}$ superiores del suelo en el Parque Estadual Mata do Pau-Ferro, Areia, PB.

\begin{tabular}{|c|c|c|c|c|c|c|c|c|c|c|c|c|c|}
\hline $\mathrm{pH}$ & $\mathrm{P}$ & $\mathrm{K}^{+}$ & $\mathrm{Na}^{+}$ & $\mathrm{H}^{+}+\mathrm{Al}^{3+}$ & $\mathrm{Al}^{3+}$ & $\mathrm{Ca}^{2+}$ & $\mathrm{Mg}^{2+}$ & SB & CEC & SOM & Sand & Silt & Clay \\
\hline $\mathrm{H}_{2} \mathrm{O}$ & \multicolumn{2}{|c|}{$\mathrm{mg} \mathrm{dm} \mathrm{m}^{-3}$} & \multicolumn{7}{|c|}{ cmolc dm ${ }^{-3}$} & $\mathrm{~g} \mathrm{~kg}^{-1}$ & & $\mathrm{~g} \mathrm{~kg}$ & \\
\hline 5.21 & 6.76 & 104.89 & 0.08 & 9.74 & 0.75 & 0.50 & 3.55 & 8.44 & 18.18 & 58.55 & 650 & 163 & 187 \\
\hline
\end{tabular}


$\left[\mathrm{ICE}=\mathrm{A} / \mathrm{Ci},\left(\mu \mathrm{mol} \mathrm{m}^{-2} \mathrm{~s}^{-1}\right)\left(\mu \mathrm{mol} \mathrm{mol}^{-1}\right)^{-1}\right]$ were calculated. The measurement protocol with IRGA was: $6 \mathrm{~cm}^{2}$ leaf chamber attached with a natural light sensor, 50-60\% air humidity, $300 \mu \mathrm{mol} \mathrm{s}^{-1}$ airflow and $400 \mu \mathrm{mol} \mathrm{CO} \mathrm{mol}^{-1} \mathrm{mi}-$ xer (model 6400-01). Analyses were performed on healthy fully-expanded leaves at the middle third of each individual, from 11:00 am to 12:00 pm and on a cloudy day.

Chlorophyll indices. Chlorophyll (Chl) content (as Falker Chlorophyll Index - FCI) was measured using a portable chlorophyll meter (ClorfiLOG ${ }^{\circledR}$, model CFL 1030), in which chlorophyll a $(\mathrm{Chl} a)$, chlorophyll $\mathrm{b}(\mathrm{Chl} b)$ and total chlorophyll $(\mathrm{Chl} a+b)$ were recorded. Subsequently, the ratio between the chlorophyll $\mathrm{a}$ and $\mathrm{b}$ indices was calculated $(\mathrm{Chl} a / \mathrm{Chl} b)$. Four readings were performed on leaves at the middle third of each plant to calculate average.

Canopy structure indices. Leaf area index (LAI), visible sky fraction (VSF) and photosynthetically active radiation (PAR) were measured using hemispherical photographs taken using a forest canopy analyzer (Digital Plant Canopy Imager, CI-110, CID). Measurements were performed above the $P$. racemosa individuals in the forest understory. To achieve better contrast between leaves and sky, analyses were performed under diffused light conditions.

Soil moisture and temperature. Soil moisture (SM) was determined using the gravimetric method proposed by Klein (2008) and calculated as:

$$
\mathrm{SM}(\%)=[(\mathrm{WW}-\mathrm{DW}) / \mathrm{DW}] \mathrm{x} 100
$$

where WW is the weight of wet sample (g) and DW is the weight of dry sample (g).

Correspondingly, soil temperature was measured on the surface $\left(\mathrm{ST}_{0 \mathrm{~cm}}\right)$ and at $20 \mathrm{~cm}$ depth $\left(\mathrm{ST}_{20 \mathrm{~cm}}\right)$ using a portable digital infrared thermometer (Raytek, MT6 model). Soil moisture and temperature were measured at the same time that ecophysiological variables were assessed once a week.
Statistical analyses. Data were submitted to a multivariate analysis using Canonical Correlation Analysis (CCA) and Principal Component Analysis (PCA) to verify associations between the environmental (LAI, VSF, PAR, SM, $\mathrm{ST}_{0 \mathrm{~cm}}, \mathrm{ST}_{20 \mathrm{~cm}}$, Rain and Temp) and ecophysiological (A, $\mathrm{Ci}, \mathrm{E}$, gs, WUE, iWUE, ICE, Chl $a$, Chl $b$ and $\mathrm{Chl} a+b$ ) variables. Besides, Wilks' lambda test (an approximation of $\mathrm{F}$ distribution) was used to analyze the significance of canonical roots. Moreover, the analysis of variance was used to test differences in ecophysiological variables over the months, followed by the Tukey test to group means $(P \leq 0.05)$. Statistical analyzes were performed in SAS ${ }^{\circledR}$ 9.3.5 software.

\section{RESULTS}

Influence of environmental factors on the P. racemosa ecophysiology. According to CCA, there were correlations between environmental and ecophysiological variables. However, only the first and second canonical dimension were significant, with $\mathrm{R}^{2}$ equal to 0.979 and 0.784 , respectively (table 2).

Likewise, for the first canonical dimension, the most important variables were rainfall, soil moisture and leaf area index $(0.87,0.79$ and 0.69 , respectively), which positively correlated with intercellular $\mathrm{CO}_{2}$ concentration $(0.85)$, transpiration rate $(0.80)$, chlorophyll a $(0.75)$, total chlorophyll (0.74), chlorophyll b (0.72), stomatal conductance $(0.70)$, net photosynthesis $(0.67)$, instantaneous carboxylation efficiency $(0.65)$, water use efficiency $(0.63)$ and intrinsic water use efficiency (0.59) (table 3).

According to the principal component analysis (PCA), it was noted that axes 1 and 2 corresponded respectively to $32.89 \%$ and $17.06 \%$ of the total inertia, explaining $49.95 \%$ of data variability (figure 3 ). Moreover, stomatal conductance (gs), transpiration rate (E) and total chlorophyll (Chl a) strongly correlated with rainfall, while chlorophyll a (Chl $a$ ), chlorophyll $\mathrm{b}(\mathrm{Chl} b)$ and intercellular $\mathrm{CO}_{2}$ concentration $(\mathrm{Ci})$ strongly correlated with soil moisture (SM). On the other hand, leaf area index (LAI) correlated with instantaneous carboxylation efficiency (ICE), net

Table 2. Wilks' lambda multivariate test (an approximation of $\mathrm{F}$ distribution).

Prueba multivariante lambda de Wilks (una aproximación de la distribución F).

\begin{tabular}{lccccc}
\hline Canonical dimension & $\mathrm{R}^{2}$ & $\mathrm{~F}$ & $\mathrm{DF}_{1}$ & $\mathrm{DF}_{2}$ & $P$-value \\
\hline 1 & 0.979 & 7.35 & 80 & 528.6 & $<0.0001$ \\
2 & 0.784 & 2.40 & 63 & 473.5 & $<0.0001$ \\
3 & 0.500 & 1.15 & 48 & 417.3 & 0.238 \\
4 & 0.435 & 0.82 & 35 & 359.9 & 0.754 \\
5 & 0.248 & 0.41 & 24 & 301.2 & 0.994 \\
\hline
\end{tabular}

$\mathrm{R}^{2}$ : canonical correlation; $\mathrm{F}$ : approximate $\mathrm{F}$ value; $\mathrm{DF}_{1}$ : treatment degrees of freedom; $\mathrm{DF}_{2}$ : error degrees of freedom. 
Table 3. Canonical correlations and canonical dimension between environmental and ecophysiological variables.

Correlaciones canónicas y par canónico entre variables ambientales y ecofisiológicas.

\begin{tabular}{lc}
\hline Variables & $\begin{array}{c}\text { Canonical } \\
\text { dimension }\end{array}$ \\
\hline Environmental & 0.69 \\
Leaf area index (LAI) & -0.19 \\
Visible sky fraction (VSF) & -0.06 \\
Photosynthetically active radiation (PAR) & 0.79 \\
Soil moisture (SM) & -0.09 \\
Soil temperature at $0 \mathrm{~cm}\left(\mathrm{ST}_{0 \mathrm{~cm}}\right)$ & -0.45 \\
Soil temperature at $20 \mathrm{~cm}\left(\mathrm{ST}_{20 \mathrm{~cm}}\right)$ & 0.87 \\
Rainfall (Rain) & -0.24 \\
Average temperature (T ave) & -0.12 \\
Maximum temperature (T max) & -0.16 \\
Minimum temperature (T min) & \\
\hline
\end{tabular}

Ecophysiological

Net assimilation rate of $\mathrm{CO}_{2}(\mathrm{~A})$

0.67

Stomatal conductance (gs)

0.70

Transpiration (E)

0.80

Internal $\mathrm{CO}_{2}$ concentration $(\mathrm{Ci})$

0.85

Instantaneous water use efficiency (WUE)

0.63

Intrinsic water use efficiency (iWUE)

0.59

Instantaneous carboxylation efficiency (ICE)

0.65

Chlorophyll $a(\mathrm{Chl} a)$

0.75

Chlorophyll $b(\mathrm{Chl} b)$

0.72

Total chlorophyll $(\mathrm{Chl} a+b)$

0.74

Chl $a /$ Chl $b$ ratio

0.28

$\mathrm{R}^{2}$

0.98

Significance

$* *$

**Significant at $1 \%$ probability by the Chi-Square test; $\mathrm{R}^{2}$ : canonical correlation.

photosynthesis (A), water use efficiency (WUE) and intrinsic water use efficiency (iWUE) (figure 3).

For axis 1 (first principal component), the eigenvectors of LAI, instant carboxylation efficiency (ICE), water use efficiency (WUE) and intrinsic water use efficiency (iWUE) are grouped right side, presenting positive values. In contrast, the eigenvectors of PAR, $\mathrm{ST}_{0 \mathrm{~cm}}$, VSF, Tave, Tmax, Tmin and $\mathrm{ST}_{20 \mathrm{~cm}}$ are arranged left side, showing negative values. This distribution of eigenvectors demonstrates, therefore, that the environmental variables are distinct from the ecophysiological ones (figure 3).

Analysis of ecophysiological aspects over the months. Significant differences were observed for the ecophysiological variables over the months $(P \leq 0.05)$, except for iWUE $(P=0.0672)$ and $\operatorname{ICE}(P=0.0939)$ (figures 4,5 and 6$)$.

In the gas exchange analysis, net photosynthesis (A) ranged from 0.516 (October) to $2.380 \mu \mathrm{mol} \mathrm{m}^{-2} \mathrm{~s}^{-1}$ (April) (figure 4A). Likewise, stomatal conductance (gs) was lower in months with water deficit and highest irradiance, ranging from 0.019 (September) to $0.082 \mu \mathrm{mol} \mathrm{m}^{-2} \mathrm{~s}^{-1}$ (April) (figure 4B). Transpiration rate (E) varied similarly to stomatal conductance (gs), ranging from 0.676 (September) to $1.690 \mathrm{mmol} \mathrm{m}^{-2} \mathrm{~s}^{-1}$ (April) (figure 4C). Intercellular $\mathrm{CO}_{2}$ concentration $(\mathrm{Ci})$ reduced in months with lower LAI and water availability, with rates fluctuating from 241.24 to $407.51 \mu \mathrm{mol} \mathrm{mol}^{-1}$ (figure 4D).

Water use efficiency (WUE) changed significantly over the months, reducing $66 \%$ from June to October [2.420 to $\left.0.819\left(\mu \mathrm{mol} \mathrm{m}^{-2} \mathrm{~s}^{-1}\right)\left(\mathrm{mmol} \mathrm{m}^{-2} \mathrm{~s}^{-1}\right)^{-1}\right]$ (figure $\left.5 \mathrm{~A}\right)$. Differently, intrinsic water use efficiency (iWUE) and instantaneous carboxylation efficiency (ICE) did not vary along months (figures 5B and 5C).

$\mathrm{Chl} a$, Chl $b$ and Chl $a+b$ were higher in the season of low irradiance and high water availability, with the highest values found in March (43.53, 25.70 and 69.44 FCI, respectively) (figures $6 \mathrm{~A}, 6 \mathrm{~B}$ and $6 \mathrm{C}$ ), while the $\mathrm{Chl} a$ / $\mathrm{Chl} b$ ratio did not oscillated, remaining constant over the months (figure 6D).

\section{DISCUSSION}

CCA and PCA analyses showed that the ecophysiological and environmental variables were significantly correlated, indicating that the ecophysiology of P. racemosa plants was influenced by environmental (abiotic) factors. Therefore, the species has variability in gas exchange and chlorophyll contents and those variabilities were correlated with changes in environmental traits. In other words, P. recemosa has the capacity to change its phenotype in response to environment; i.e it has phenotypic plasticity in the traits evaluated. Thus, according to CCA (Hair Junior et al. 2009), rainfall, soil moisture and leaf area index are considered the most important environmental factors that increased gs, E, Chl $a$, Chl $b$, Chl $a+b, \mathrm{Ci}, \mathrm{A}, \mathrm{ICE}$, WUE and iWUE in P. racemosa. On the other hand, PAR and VSF, two variables related with canopy coverage, correlated negatively with ecophysiological traits though showed to be weaker than rainfall. Therefore, seasonal variation in gas exchange and photosynthetic pigments of understory plants may be caused by edaphic factors and forest canopy opening, such as soil water availability and leaf area index that modify the shade to the understory species (Giuggiola et al. 2018), although in this case, soil water content seems to be more important than light. 


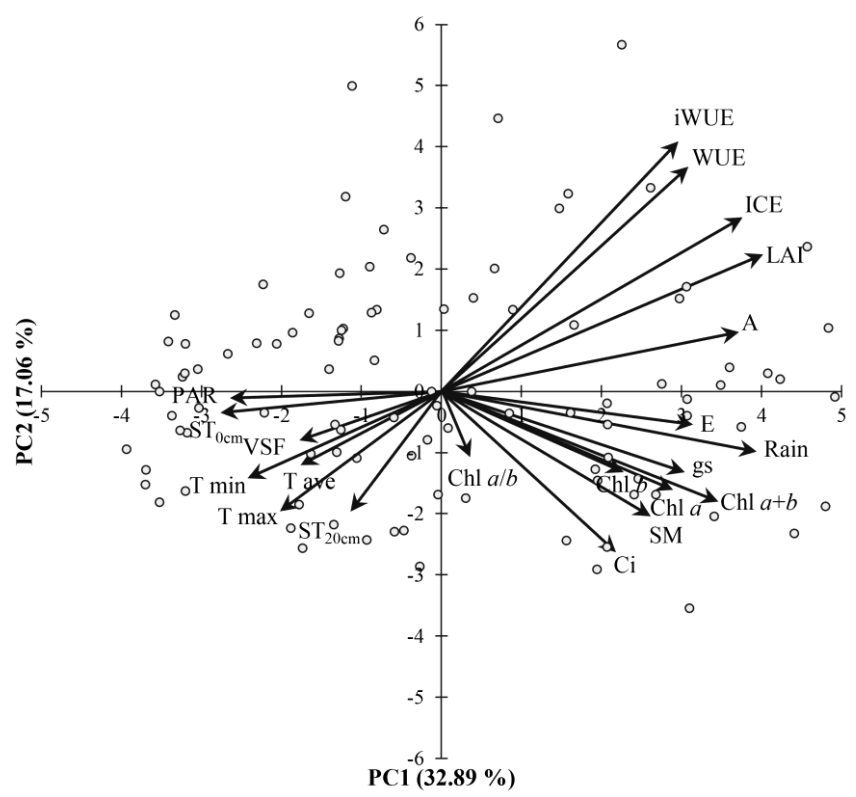

Figure 3. Principal Component Analysis (PC1 and PC2) for environmental and ecophysiological variables in P. racemosa individuals. Abbreviations are presented in table 3.

Análisis de componentes principales (PC1 y PC2) para variables ambientales y ecofisiológicas en individuos de P. racemosa. Las abreviaturas se presentan en el cuadro 3 .
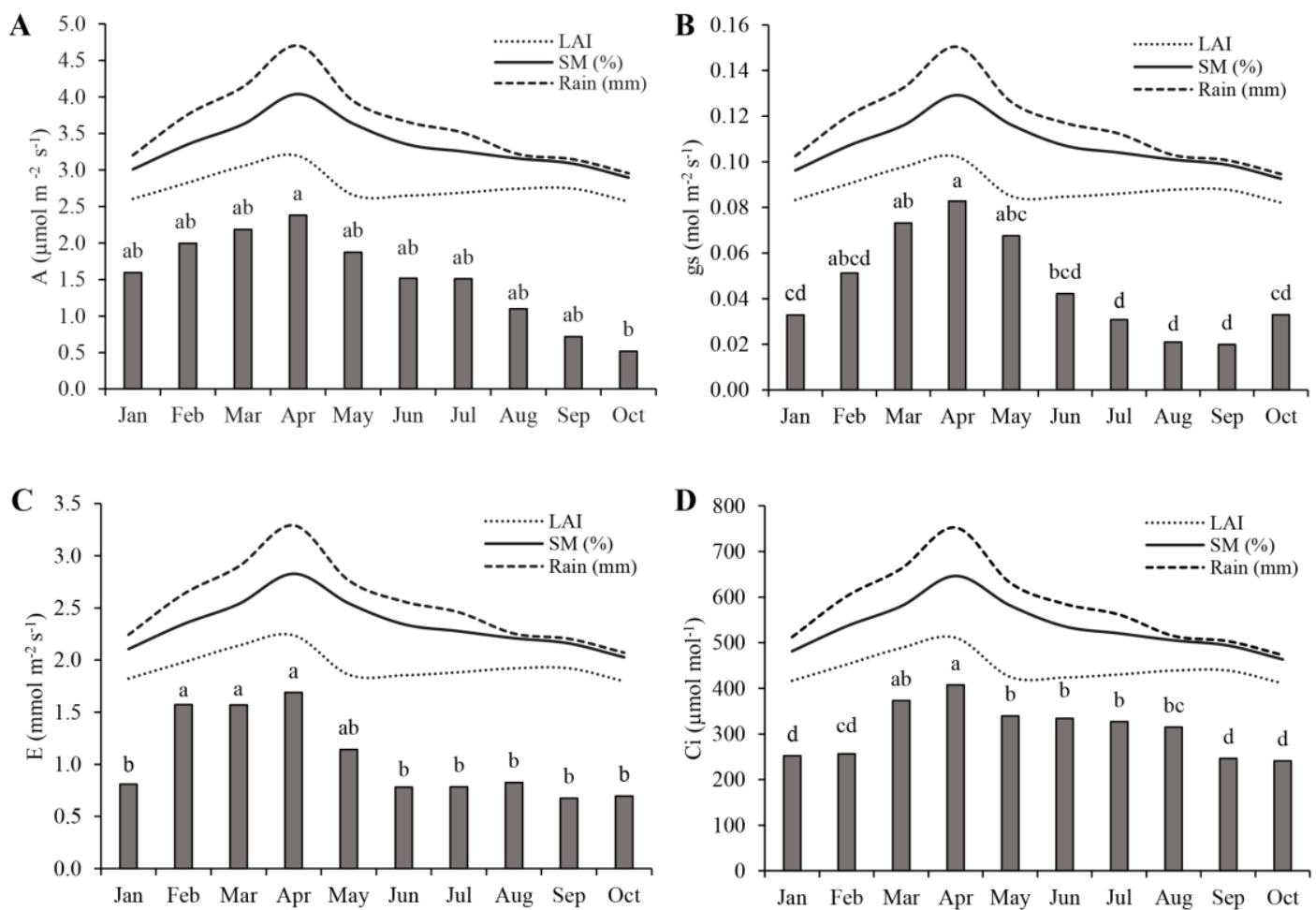

Figure 4. Means of (A) net photosynthesis, (B) stomatal conductance, (C) transpiration rate and (D) intercellular $\mathrm{CO}_{2}$ concentration in P. racemosa plants compared by the Tukey test, along with rainfall (Rain), soil moisture (SM) and leaf area index (LAI), over the months at Parque Estadual Mata do Pau-Ferro, Areia, PB.

Medias de (A) fotosíntesis neta, (B) conductancia estomática, (C) tasa de transpiración y (D) concentración de $\mathrm{CO}_{2}$ intercelular en plantas de $P$. racemosa en comparación con la prueba de Tukey, junto con lluvia (lluvia), humedad del suelo (SM) e índice de área foliar (LAI), a lo largo de los meses en el Parque Estadual Mata do Pau-Ferro, Areia, PB. 
Therefore, soil water deficit and high irradiance during the dry season may have been the main factors that negatively interfered with physiological processes of $P$ racemosa plants (Maréchaux et al. 2019). Thus, under these conditions, the plants reduced stomatal conductance, $\mathrm{CO}_{2}$ assimilation and intercellular $\mathrm{CO}_{2}$ concentration (Chen et al. 2019). Hence, $\mathrm{A}$ is lower when light availability in the understory is higher, because as leaf shedding occurs during the dry season, P. racemosa plants cannot take advantage of the increase in light as stomata are partially closed. LAI is determinant in the irradiance interception by understory plants. Therefore, a canopy reduction, by anthropic actions or leaf shedding in dry seasons, increases the irradiance levels into the understory, thereby reducing the photosynthetic rate due to the excess of light (Lin et al. 2018) as plants are water stressed.

Water deficit and excessive irradiance reduce stomatal conductance (gs) as a result of stomatal closure, which consequently reduces carbon fixation. In other species a reduction in leaf area, besides accelerating leaf senescence, and abscission were observed in water stressed plants (Toïgo et al. 2020). The mechanism of stomatal opening and closing depends upon the turgescence of guard cells, evidencing that the opening is favored by adequate water availability in soil. On the other hand, reducing transpiration during the dry season is a plant defense mechanism to prevent excessive water loss. In addition to this mechanism, stomatal closure and leaf area reduction are adaptive mechanisms of plants, making plants tolerant to water stress (Griebel et al. 2019). It is evident that $P$. racemosa has no strategies to avoid water stress, like a deep root system, high hydraulic capacitance or a thick boundary layer, and it partially closes the stomata to avoid leaf dehydration, with the consequent reduction in carbon assimilation.

In the case studied, LAI reduction and the consequent increase in light available for $P$. racemosa plants occur together with soil water deficit, hence it is difficult to discriminate the effect of each factor. However, it is clear that gs changed more markedly along the months than A, thus stomatal limitations seem to be very important in the reduction of A. Moreover, the strategy of this species as SM reduces is to close the stomata and reduce transpiration during the dry season (figure 4). This idea is reinforced by the reduced intercellular $\mathrm{CO}_{2}$ concentration $(\mathrm{Ci})$ in plants in the dry season, which clearly indicates that the stomatal limitation negatively affects the resistance of mesophyll to
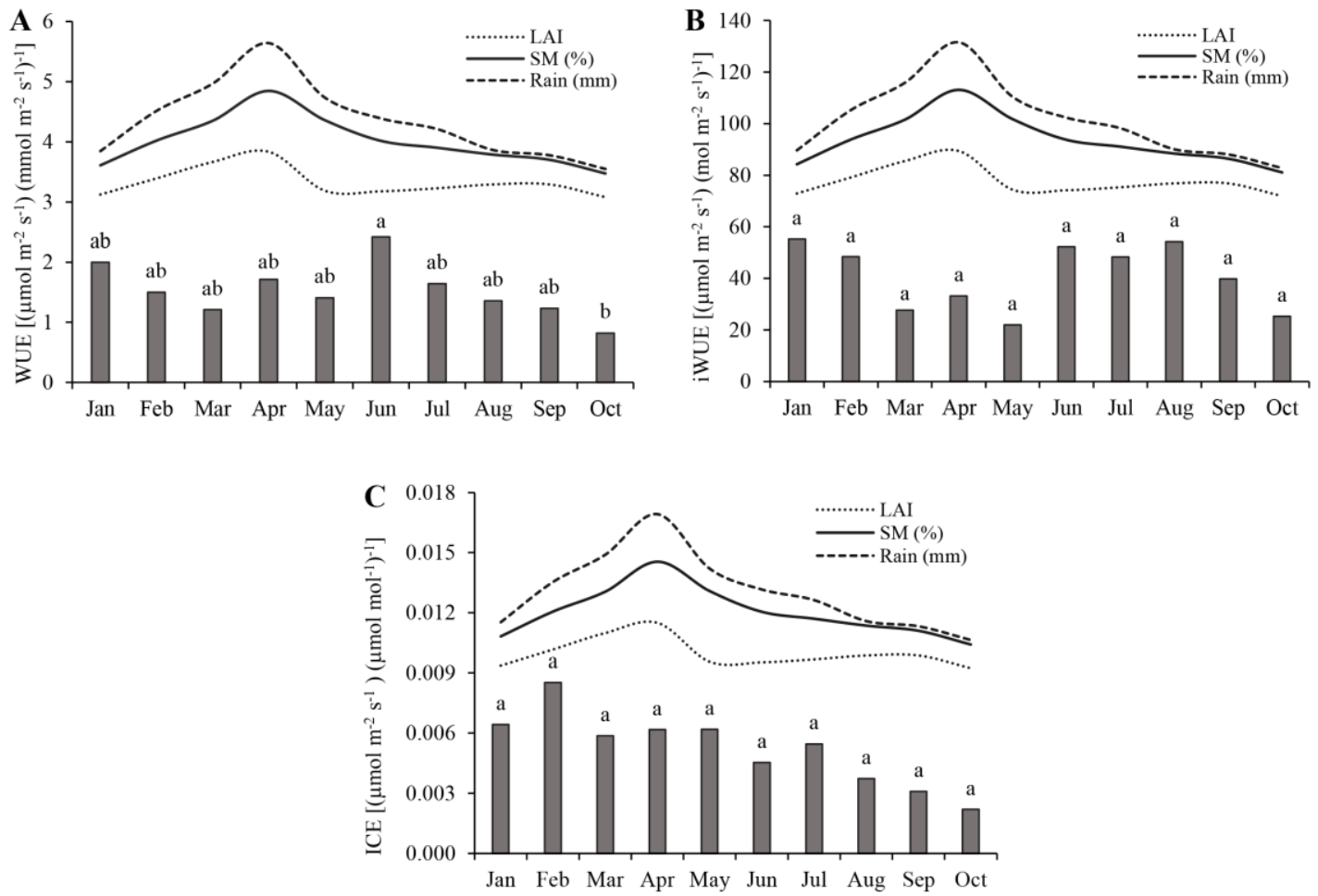

Figure 5. Monthly means of (A) water use efficiency, (B) intrinsic water use efficiency and (C) instantaneous carboxylation efficiency in $P$. racemosa plants compared by the Tukey test, along with rainfall (Rain), soil moisture (SM) and leaf area index (LAI) at Parque Estadual Mata do Pau-Ferro, Areia, PB.

Medias mensuales de (A) eficiencia en el uso del agua, (B) eficiencia intrínseca del uso del agua y (C) eficiencia de carboxilación instantánea en plantas de P. racemosa comparadas con la prueba de Tukey, junto con la lluvia (Lluvia), la humedad del suelo (SM) e índice de área foliar (LAI) en el Parque Estadual Mata do Pau-Ferro, Areia, PB. 

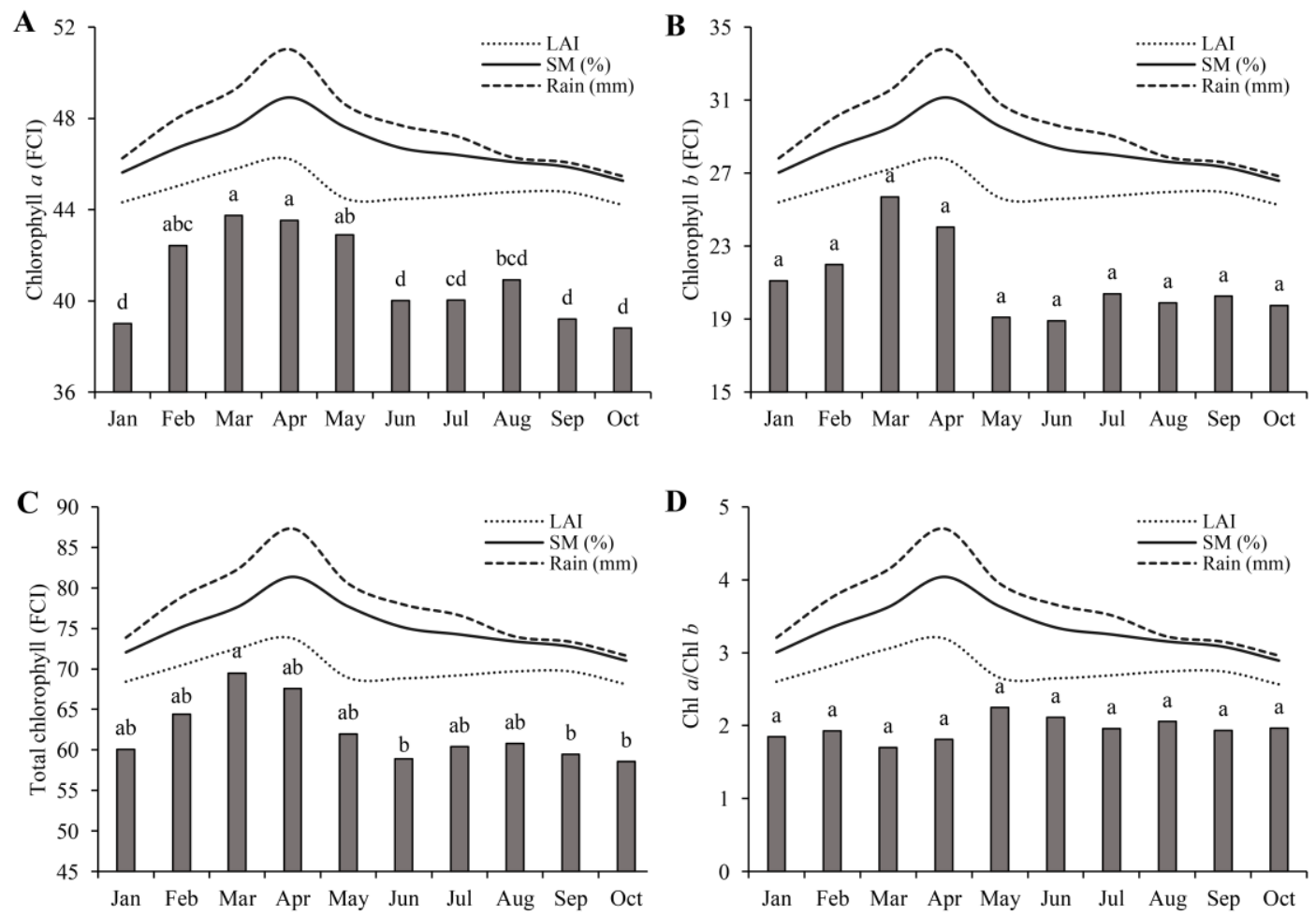

Figure 6. Monthly means of (A) chlorophyll $a$, (B) chlorophyll $b,(\mathrm{C})$ total chlorophyll and $\mathrm{Chl} a / \mathrm{Chl} b$ ratio (D) in $P$. racemosa plants compared by the Tukey test, along with rainfall (Rain), soil moisture (SM) and leaf area index (LAI) at Parque Estadual Mata do PauFerro, Areia, PB.

Medias mensuales de (A) clorofila a, (B) clorofila by (C) clorofila total en plantas de P. racemosa comparadas con la prueba de Tukey, junto con la precipitación (Lluvia), la humedad del suelo (SM) y el índice de área foliar (LAI) en el Parque Estadual Mata do Pau-Ferro, Areia, PB.

$\mathrm{CO}_{2}$ diffusion into the substomatal chamber, therefore restricting photosynthesis (Dalastra et al. 2014). In this sense, factors such as low water availability, high irradiance and reduced $\mathrm{Ci}$ can be limiting for the photosynthetic process, mainly by restricting gas conduction in leaves (Lambers and Oliveira 2019).

Water use efficiency (WUE) in P. racemosa plants was similar along the season. The only difference was between June, which had the highest WUE, and October, which had the lowest WUE. However, June was neither the wetter nor the drier period, though that month was the beginning of the dry season: at that moment gs reduced proportionally more than A (Guo et al. 2019). Conversely, intrinsic water use efficiency (iWUE) and instantaneous carboxylation efficiency (ICE) did not vary over the months. Although these physiological variables may be enhanced as a response of high A, Ci and gs (Ruzicka Júnior et al. 2017); it was not observed in the present study. It is important to remark that although light availability to $P$. racemosa was high in the dry season, that light could not be used to increase A and, consequently WUE. Thus, the species is not limited by low light availability during the wet season, although it is under a dense shade. Hence, even during the wet season plants couple stomatal opening to $\mathrm{CO}_{2}$ demands and no unnecessary water is transpired, as was observed in some nutrient-poor environments (Matimati et al. 2014).

Changes in chlorophyll content (Chl $a$ and Chl $a+b)$ over the months may have occurred as a consequence of these pigments being sensitive to excessive irradiance and water deficit in the dry season, or shade acclimation during the wet season. As $\mathrm{Chl} a / \mathrm{Chl} b$ ratio remained steady, it is evident that the species is not limited by light during the wet months, when the shade is dense. When incident light increased and SM decreased, chlorophyll concentration reduced because these environmental conditions induce pigment degradation, thus not only reducing the photosynthetic capacity of the plant (Ribeiro et al. 2018), but also protecting plants from photoinhibition and photodamage. As Chl $a / \mathrm{Chl} b$ ratio is similar in every month, chlorophyll degradation occurred both in antenna and centers of reaction, consistently with the reduction of A. It is important to highlight that the species has the capacity to increase chlorophyll concentration during the months of higher water availability and lower incident radiation, and to quickly decrease it when stressful environmental conditions start, possibly to avoid stress by the excess of light. 


\section{CONCLUSIONS}

Palicourea racemosa shows changes in gas exchange in response to dry and rainy periods. The rainfall and soil moisture are the environmental variables that most affect photosynthesis and water exchange of $P$. racemosa. The increase of incident light during the dry season induces reduction in chlorophylls concentration. Individuals from P. racemosa reduced carbon and water exchange in the dry season. The main stress apparently is soil water deficit, while plants adjust chlorophyll content to the level of shade of each season. Consequently, the maximum leaf photosynthetic rate is achieved under the shade during the wet season.

\section{ACKNOWLEDGEMENTS}

This study was financed in part by the Coordenação de Aperfeiçoamento de Pessoal de Nível Superior - Brasil (CAPES) - Finance Code 001

\section{REFERENCES}

Baraket M, S Fkiri, I Taghouti, SS Kachout, A Ennajah, A Khaldi, Z Nasr. 2020. Effect of water deficit on gas exchange responses to intercellular $\mathrm{CO}_{2}$ concentration increase of Quercus suber L. seedlings. Journal of Agricultural Science 12(1):73-83. DOI: https://doi.org/10.5539/jas.v12n1p73.

Calixto NO, MEF Pinto, SD Ramalho, MCM Burger, AF Bobey, MCM Young, VS Bolzani, AC Pinto. 2016. The genus Psychotria: Phytochemistry, chemotaxonomy, ethnopharmacology and biological properties. Journal of the Brazilian Chemical Society 27(8):1355-1378. DOI: https://doi. org/10.5935/0103-5053.20160149.

Chen CI, YN Wang, JC Yu. 2019. Diurnal and Seasonal $\mathrm{CO}_{2}$ assimilation by four plantation species in Taiwan. Forest Science 65(1):68-76. DOI: https://doi.org/10.1093/forsci/ $\underline{\text { fxy033. }}$.

Denslow JS, Chaverri S LG, Vargas R O. 2019. Patterns in a species-rich tropical understory plant community. Biotropica 51:664-673. DOI: https://doi.org/10.1111/btp.12704.

Derroire G, P Balvanera, C Castellanos-Castro, G Decocq, DK Kennard, E Lebrija-Trejos, JA Leiva, PC Odén, JS Powers, V Rico-Gray, M Tigabu, JR Healey. 2016. Resilience of tropical dry forests - a meta-analysis of changes in species diversity and composition during secondary succession. Oikos 125(10):1386-1397. DOI: https://doi.org/10.1111/ oik.03229.

Elias GA, EL Hettwer Giehl, AL De Gasper, JMT Lima, R Santos. 2019. Low temperature extremes influence both the presence of palms and palm species richness in the Atlantic Forest, Southern Brazil. Ecologia Austral 29(1):41-49. DOI: https://doi.org/10.25260/ea.19.29.1.0.737.

Giuggiola A, R Zweifel, LM Feichtinger, P Vollenweider, H Bugmann, M Haeni, A Rigling. 2018. Competition for water in a xeric forest ecosystem - Effects of understory removal on soil micro-climate, growth and physiology of dominant Scots pine trees. Forest Ecology and Management 409:241-249. DOI: https://doi.org/10.1016/j.foreco.2017.11.002.
Griebel A, LT Bennett, D Metzen, E Pendall, PNJ Lane, SK Arndt. 2020. Trading water for carbon: Maintaining photosynthesis at the cost of increased water loss during high temperatures in a temperate forest. Journal of Geophysical Research: Biogeosciences 125:1-38. DOI: https://doi. org/10.1029/2019JG005239.

Guo XY, Y Wang, PX Zhao, P Xu, GH Yu, LY Zhang, Y Xiong, CB Xiang. 2019. AtEDT1/HDG11 regulates stomatal density and water-use efficiency via ERECTA and E2Fa. New Phytologist 223(3):1478-1488. DOI: https://doi. org/10.1111/nph.15861.

Hair Júnior JF, WC Black, BJ Babin, RE Anderson, RL Tatham. 2009. Análise multivariada de dados. Porto Alegre, Brasil. Bookman. 688 p.

Jenicek M, H Pevna, O Matejka. 2018. Canopy structure and topography effects on snow distribution at a catchment scale: Application of multivariate approaches. Journal of Hydrology and Hydromechanics 66(1):43-54. DOI: $\underline{\text { https:// }}$ doi.org/10.1515/johh-2017-0027.

Klein VA. 2008. Física do solo. Passo Fundo, Brasil. Ediupf. $212 \mathrm{p}$.

Lambers H, RS Oliveira. 2019. Plant water relations. In Lambers H, RS Oliveira eds. Plant Physiological Ecology. Cham, Switzerland. Springer. p. 28-48.

Lin KH, CW Wu, Y Chang, Y Sen. 2018. Applying Dickson quality index, chlorophyll fluorescence, and leaf area index for assessing plant quality of Pentas lanceolata. Notulae Botanicae Horti Agrobotanici Cluj-Napoca 47(1):169-176. DOI: https://doi.org/10.15835/nbha47111312.

Mansur AL. 2017. O papel das clareiras de deciduidade na dinâmica de comunidades arbóreas em florestas estacionais semidecíduas. Thesis Master in Ecology. Campinas, Brazil. Instituto de Biologia, Universidade Estadual de Campinas. $134 \mathrm{p}$.

Maréchaux I, L Saint-André, MK Bartlett, L Sack, J Chave. 2019. Leaf drought tolerance cannot be inferred from classic leaf traits in a tropical rainforest. Journal of Ecology 108:1030-1045. DOI: https://doi.org/10.1111/13652745.13321.

Matimati I, GA Verboom, MD Cramer. 2014. Nitrogen regulation of transpiration controls mass-flow acquisition of nutrients. Journal of Experimental Botany 65(1):159-168. DOI: https://doi.org/10.1093/jxb/ert367.

Pausas JG, WJ Bond. 2020. Alternative Biome States in Terrestrial Ecosystems. Trends Plant Science 25(3):250-263. DOI: https://doi.org/10.1016/j.tplants.2019.11.003.

Peel MC, BL Finlayson, TA McMahon. 2007. Updated world map of the Köppen-Geiger climate classification. Hydrology and Earth System Sciences 11:1633-1644.

Ribeiro JES, AJS Barbosa, SF Lopes, WE Pereira, MB Albuquerque. 2018. Seasonal variation in gas exchange by plants of Erythroxylum simonis Plowman. Acta Botanica Brasilica 32(2):287-296. DOI: https://doi.org/10.1590/010233062017abb0240.

Ruzicka KJ, KJ Puettmann, R Brooks. 2017. Cross-scale interactions affect tree growth and intrinsic water use efficiency and highlight the importance of spatial context in managing forests under global change. Journal of Ecology 105(5):1425-1436.

Sun H, SB Zhang, T Liu, W Huang. 2020. Decreased photosystem II activity facilitates acclimation to fluctuating light in 
the understory plant Paris polyphylla. Biochimica et Biophysica Acta - Bioenergetics 1861(2):1-8. DOI: https://doi. org/10.1016/j.bbabio.2019.148135.

Toïgo M, M Nicolas, M Jonard, L Crois'e, L Nageleisen, H Jactel. 2020. Temporal trends in tree defoliation and response to multiple biotic and abiotic stresses. Forest Ecology and Management 477: 1-10. DOI: https://doi.org/10.1016/j.foreco.2020.118476.
Vijith H, D Dodge-Wan. 2020. Spatial and temporal characteristics of rainfall over a forested river basin in NW Borneo. Meteorology and Atmospheric Physics 132:683-702. https://doi.org/10.1007/s00703-019-00714-4.

Zappi DC, LM Miguel, SV Sobrado, RM Salas. 2017. Flora das cangas da Serra dos Carajás, Pará, Brasil: Rubiaceae. Rodriguesia 68(3):1091-1137. DOI: https://doi. org/10.1590/2175-7860201768347.

Recibido: 11/09/20

Aceptado: 29/03/21 